\title{
The Influence of Tourism Business Licensing toward the Absorption of Local Manpower
}

\author{
Mia Kusuma Fitriana, Abdul Munif, Fatimah Asyarie \\ Faculty of Law \\ University of 17 Agustus 1945 \\ Samarinda, Indonesia \\ miakusuma2001@gmail.com
}

\begin{abstract}
This study examines the role of licensing law in order to drives the absorption of local manpower. We used conceptual and statute approaches to legislation in designing the study. As this kind of study belongs to normative work, data collected are in the form of articles of the acts on and related to licensing, the theories of tourism and business, and related literatures obtained from library through documentation. The data were analyzed and presented qualitatively. The results show that Licensing Laws may encourage the absorption of Local Labor with permission essence, which has a driving force. Because carefully this tool of coercion then the business industry needs to comply with regulations to be allowed issued by the Regional Government. To make effective local labor recruitment, every local government needs to make local government regulations that regulate the obligation of every tourism business to employ local workers.
\end{abstract}

Keywords-tourism business; licensing law; absorption; local manpower

\section{INTRODUCTION}

The tourism sector is a promising business if it can be managed properly and seriously. Even in 2016 Indonesia's Foreign exchange from tourism sector is in second place after CPO amounted to U\$ 13.568 billion, already beating the one that came from oil and gas [1].This income shown the high selling value of Indonesia's tourism, that could bring prosperity throughout the tourism driving community or people in the region that have tourism objects.

However, this does not seem to work as it should be, because the tourism sector has not fully overcome the problems of local employment. In practice, the tourism sector actually employed many workers outside the region, while the local workforce of executive rather than the technical personnel, especially the experts. What need to be happened is that the tourism and it industries play an important part in an effort in an effort to increase more local employment got a job, thus it will impact on the decrease of unemployment rate.

Government and private sector plays a very significant role in order to solve the unemployment problems. Since both of them are the one that can drive tourism industries. Because, tourism industry is a collection of tourism businesses are interrelated in order to produce goods and / or services for the needs of tourists in the implementation of tourism. The running of these industries are depend on how the government and private sector drives it, beside the involvement of society that also important. The growth of tourism objects that increase every year might cause overwhelming task for government to cope. In this situation private sector need to take a place. Government can work together with the private sector thus the tourism industries can keep move forward and at the end increasing the state income.

Private sector role in tourism is very important as all we know most of thing managed by private sector tend to be more professional and well-managed in running the business. Moreover, not all of the development and maintenance toward tourism objects are borne by state budget, thus it need the cooperation with private sector. Private sector shall play it role not only as investor but also responsible for the advance and development of tourism and it industries because no matter what the main thing of tourism business laid upon satisfying services provide.

Government takes it part in tourism industries as it responsible for four main things; planning areas or areas of tourism, development main facilities and support tourism, policy spending tourism, and the manufacture and enforcement of regulations. In a planning of tourism it consist of economic development that can drive the growth of any industries relate to tourism, location planning, infrastructure planning such as road; airport; electricity as such, social planning include the provision of employment, security plans that includes internal security for tourist destinations and tourists. In the development of tourism it usually done by the private sector, however the public infrastructure is the responsibility of government. In the enforcement of law and regulation, government is the center of it. Since the making and the enactment of regulation start and driven by Government.

Regulation about tourism plays very important role in protecting tourist and it industries. Important rules that need to be made by the government for those purposes are rules of protection of tourists, especially for travel agents, tours and others; regulation about fire-related security, and competency standard related to its workers. Relates to workers, one of the main factor of how business industries can run other than government, regulations and private sectors. Private sector cannot run it business without manpower that works in it. Private and manpower is relating in term of tourism business 
that run by private where the manpower as the executant of the business. Private owner impossible to run it business without the workers and workers could have a working opportunity when the private open it possibilities. Meanwhile, government can be connecting bridge between them with regulations as the tools because legislation making is in the hand of government. Thus any laws, regulation and legally binding rules that has legal consequences and it changes can be made under the authority of the government. Therefore, in order to harmonize the working relation between private sector and the manpower it needs legal bases thus all the rights and obligation toward parties can be fulfilled.

In some regulation actually already mentioned the obligation of private sector to hire local worker, though it seems that it has not work well in some places in Indonesia. Although Bali has proven that the growth of tourism business contributing the large number of local worker absorption but unfortunately is doesn't happened the same way as other region in Indonesia, especially in East Kalimantan. In the practice shows that the growth of tourism business did not followed by an increase of the manpower absorption, especially local manpower since the tourism object and industries belong to region that has a tourism objects. Tourism business is contributing a high number of manpower absorption, however does it represent the number of local manpower where the tourism objects related, this will be discussing deeper in this paper. Other that discussion, in this paper also need to analyze effective mechanism that can drive the high number of local manpower absorption which is through the licensing regulation that shall be owned by every region in Indonesia especially those who has tourism potential. Since the practices of private sector obligation that has been regulates in certain laws and regulation nationally especially cannot guarantee that the local manpower of those tourism region are absorb. For example in East Kalimantan whereas the tourism business and objects continues to grow year after year however the local manpower still need more struggle to be hired by this industries, since the job opportunity contested together with manpower comes across the region not only East Kalimantan but overland or even across the country. Thus the growth of tourism business does not directly proportional with the growth of local manpower absorption.

The laws and regulation that has been made is not enough to contemplate the problems of the absorption of local manpower especially in East Kalimantan, therefore in preliminary research was find possibility in enacting Licensing Law of the region in order to push or to drive tourism sector to absorb local manpower as much as possible. This concept occur since the growth of the tourism industries that keep growing multiple in numbers that need the license for sure, thus that they can operate or start running their business. When they not fulfilling the requirements of having the tourism business permit then they cannot do their business. It could be more effective rather than depend on the other regulation.

This paper tries to formulate how the licensing law can be used as the instrument in order to drives the absorption of local manpower, relate the mechanism of the licensing business permit issuance.

\section{METHOD}

This study used conceptual and statute approach to legislation to explore library data on Licensing Law and tourism business. To accomplish the take of the data, library study was applied with utilization of documentation technique. The data collected including articles ruling the Licensing legal provisions, theories of tourism and business, and other related studies and literature in the correlation between tourism and Licensing Law. Data were analyzed and presented qualitatively.

\section{RESULT AND DISCUSSION}

\section{A. The Role of Licensing Law in Driving the Absorption of Local Manpower}

In Indonesia, Licensing law is part of administrative law. Licensing law relates with public law, as it principles relating to the law of exclusion where there are civil aspects of consent as well as in the granting of special permits. Permission is an act of State-First Administrative Law that is applied in the rules based on the requirements and procedures as the provisions of legislation. Basically the law of licensing is the law governing public relations with the State in the event of a society requesting permission.

Article 53 paragraph 2 The Law on State Administrative Court categorizes licenses as state administrative decisions / decisions. Therefore, the basis of the test of the validity of a State administrative decree includes two matters, namely: the prevailing laws and regulations and the general principles of good governance. State administrative decisions / government decisions are said to be valid if in accordance with applicable laws and regulations, in the case of: contents or substances contained therein. Example: a local regulation stipulates that the applicable IMB in a district must include the number of applications for building permit, name of applicant / owner of building, address, permitted activities, building function, building type, building name, building area, right to land, land area, on behalf of / landowner, building site, building construction, construction period; procedures and decision forms, For example: a local regulation stipulates that a request for a fault permit must be accompanied by a signature of the neighbors in the north, south, east and west where the activity is carried out and the approval of the head of RT, RW, and the local village head; the authority of the government organs to decide. Authority is important because the subject of public law can only perform public legal acts when equipped with authority.

Licensing according to established legislation, always contains important provisions that prohibit unlawful citizens from acting. In connection with such provisions as it consequences, then in the framework of law enforcement in question, equipped also with the provision of sanctions. This sanction is the most important fair cover of the law including the administrative law, because any statutory law containing orders or prohibitions, if not accompanied by sanctions, then the effectiveness of the rule no longer has any force.From the long-term explanation of the permit above it can be concluded that the permit is the act of a one-sided government based on 
legislation to be applied to concrete events according to certain procedures and requirements.

As emphasized by Sjachran Basah [2] that sanctions are the most important part of any law, the existence of orders and restrictions contained in any law, has no meaning if it has no force to exercise. It is clearer that the set is of a type of legislation that is categorized as forcing. In the event of a breach of any statutory regulations shall be subject to sanctions. Then it is also affirmed that the permit elements include [2]: tool of power (machtsmiddelen), public legal (publiekerchtlijke), used by the ruler (overhead), as a reaction to disobedience (rechteopnietnaleving). While the sanctions generally known in the field of administrative law are [2];

- Government forced action.

- Withdrawal of favorable State Administrative Decree.

- The imposition of criminal sanctions and or imprisonment.

- Forced imposition by the government (dwangsom).

Licensing is closely related to the community, because it relating government and society. The government task is to organize the community to follow the required ways and the duty to provide public services. The elements that are regulated in licensing are:

- Parties;

- Regulating objects;

- Legalization ;

- The authorities who issue the permit;

- Tenure;

- Permission use; and

- Issuance reasons either delegations or attributions.

Moreover, licensing has function and purpose such as a government instrument, the license to serve as the spearhead of the legal instrument as the director, engineer, and designer of the just and prosper society is incarnated. Regarding the purpose of licensing in general are as follows [3]:

- The desire to direct certain activities;

- Permission to prevent harm to the environment (environmental permits);

- The desire to protect certain objects (flying permits, dismantling permits on monuments);

- Permission to share small objects (permit dwellers in densely populated areas); and

- Permission to provide direction, by selecting persons and activities.

Administrative law has been developed since the government start to organize the society through the use of law, for example by the enactment of decisions, regulations and certain prohibition or by issuing the permit. The purposes of licensing law are in order for legal certainty, protection of public interest, prevention of damages or environment disaster, the equal distribution.

The welfare state conspiracy refers to the role of the State that actively manage and coordinates the economy. Therefore, it has to be a welfare system as people social rights that need to be balance with the economic growth and the job opportunity. Thus in order to achieve the social welfare other economic growth the job opportunity also need to be fulfilled. There is a lot effort that has been done in order to provide more job opportunity especially for local manpower, although it has not found the effective one. Since one of the indicator of a welfare state is the job opportunity thus it needs to be solve, one of them is by using licensing las as the forcing tools that can drive the absorption of local manpower.

\section{B. Tourism Business Licensing Trigger on Local Manpower Absorption}

In line with the enactment of Law Number 23 Year 2014 about Regional Government, where the regions are given the power or authority to regulate their own households and thus the local government must finance its expenditure by using its regional income because the central government is unlikely to bear all the expenditure of the existing area [4]. Given these conditions, the local government imposed a provision on licensing that can increase regional income and to run the orderly administration.

Moreover, based on Minister of Tourism Regulation Number 18 Year 2016 about Registration of Tourism Business, it is mentioned that tourism Business is a business that provides goods and / or services for meeting the needs of tourists and the implementation of tourism [5]. Thus everything that relate to tourism business has to own the permit, some of them are the tourism business covers the business field [5]:

- Tourist attraction;

- Tourism areas;

- Travel transportation services;

- Travel services;

- Food and beverage services;

- Accommodation provision;

- Organizing entertainment and recreation activities;

- Organizing meetings, incentive trips, conferences, and exhibitions;

- Tourism information services; j. tourism consultant services; k. guides services;

- Tourist water; and

- Spa.

All of those kind of businesses are need to own Tourism Business Register Certificate, hereinafter abbreviated as TDUP, is an official document given to the Tourism Entrepreneur to be able to organize a tourism business. Without TDUP tourism business cannot start to operate. Every Tourism 
Entrepreneur in conducting tourism business shall be obliged to register the tourism business. Registration of tourism business is addressed to PTSP Regency/City. Tourism business registration stages include:

- Application for registration;

- Examination of application file; and

- Publishing TDUP.

After the TDUP is issued, then the government has it authorities to do the supervision through report that has to be made by the tourism entrepreneur. Tourism Entrepreneur reports tourism business activities to the Regent/Mayor through the Regional Device Work Unit in charge of tourism every 6 (six) months. Whereas the report of tourism business activities shall include business development and input to the Regional Government.

The report on the results of the registration of tourism business and the report of tourism business activities includes: name of tourism business; location and/or tourism business office; number of tourism businesses; changes in the number of tourism businesses compared with the reporting in the previous period; an explanation of the matters causing the change in the number of tourism businesses as referred to in letter $d$, especially in the event of a reduction; and reports on tourism business activities

There are also sanction toward the violation of this regulation from administrative sanction in form of verbal reprimands up to revocation of TDUP as intended in to Tourism Entrepreneur who:

- Subject to sanction of permanent termination of business activities in accordance with the provisions of laws and regulations;

- Not conducting business continuously for a period of 1 (one) year or more; or

- Submit falsified documents at the time of registration of tourism business and / or TDUP updating.

The regulation about TDUP is so rigid and hard one, thus the violation of it can cause a serious sanction for tourism entrepreneur. All the requirement and criteria of it has to be fulfilled. This would be most effective if the affairs associated with the issuance of TDUP could be attributed to employment absorption.

If only the requirement mentioned in the TDUP relate to the absorption of local manpower such as minimum number of local worker that should be hired and the composition of its worker has to be dominated by local worker rather than worker that originally come from outside the region as being proven by the identity card, then it will be a guarantee for the local worker that they right to own a job within their region provide by the entrepreneur that will run their business within the areas. This condition will not only be occurring good effect for the local worker but for the entrepreneur as well. Because if the business guarantee that the local worker will be hired then it may be supported by the local resident thus it could help the business run well.
However, since the TDUP is not regulates about the absorption of local manpower as one of its requirement of TDUP issuance then it needs be regulated in another legal instrument. One of the legal instrument that possibly contain the provision about absorption of local is Local Regulation that becomes the authorities of Local Government. Through the Local Regulation relates the licensing of tourism business it can regulate the issuance of tourism business permit that belong to Local Government authorities. The substance of the Legal regulation should contain requirement that need to be fulfilled by the applicants in this case is the entrepreneur. One of the requirement such as of minimum local manpower that should be recruited. If the minimum number of local manpower that need to be recruited in its practice did not fulfilled then the sanction can be charged in form of written warning up to the revocation of it tourism license.

The Local Regulation that can regulate about the tourism business can be named as the Local regulation about Tourism Business Licensing. This local regulation will regulate about the Business Tourism Facilities, Tourism Services Business; and Exploitation of Tourism Objects and Attraction. This Local regulation shall regulate about the requirement of tourism business licensing issuance. One of the criteria that should be fulfilled by the entrepreneur so that the tourism business issuance can be issued by the Local Government is about the minimum number of local manpower that should be recruited during the operation of the business. Moreover, this local regulation should also contain guidance and supervision, in which regulates about the evaluation of the permit. When the ongoing operation of the business it is proven does not fulfilled the minimum local manpower that being hired, then the permit can be revoked. This requirement will drive the absorption of local manpower more effective.

Local Regulation about Tourism Business Permit issuance that can be made by the Local Government there are some elements in it that has to be there in the regulation such as:

- Authority.

- As a form of provision.

- Government Institutions.

- Rights and Obligations.

- Concrete events.

- Processes and procedures.

- Specific requirements.

- Permission completion time.

- License fee.

- Supervision of licensing.

- Completion of complaints and disputes; and

- Sanctions.

In that Local Government Regulation, the substance about obligation of every business industries that runs within the region to hire local worker can be loaded in part rights and 
obligations of the applicants (entrepreneur). One of the obligation that should be obeyed by the applicant is to hire local worker, thus it has to be fulfilled by the applicant in the future when the business run. The minimum number of local worker that has to be hired can be laden in the specific requirement. In this part can contain the regulation of how many local workers that shall be hired the composition of local worker compares to worker that come outside the region whether in form of number or percentage. Meanwhile, supervision relate it obligation to hire local worker as mentioned in the local government regulation can be loaded in the supervision licensing. If it is suspected that the entrepreneur does not obey it obligations to hired certain number of local worker, then the government can take step into the oral and written warning within certain period of time, when the entrepreneur ignored or cannot perform it obligation to hire certain number of local worker then the local government has the authority to revoke the permit. The conditions of how the permit can be revoked can be loaded in the part of sanction.

Therefore, by the local government regulation then provisions about the obligation to hire local worker can be implemented effectively. Through this mechanism then the private sector can be pushed to hire local worker, thus the absorption of local manpower can be implemented effectively. Since other mechanism already proven not effective enough in attempt to increase the absorption of local manpower, then this effort through Local Government Regulation need to try.

\section{CONCLUSION}

Licensing Law can drive absorption of Local Manpower with the essence of the permit that has the forcing power. Because thorough this forcing tool then the business industries need to obey the rules in order to have to permit being issued by the Local Government. Tourism Business Permit can be the trigger of Local Manpower absorption. The issuance of tourism business permit can be regulated in Local Government
Regulation that regulate about the obligation of entrepreneur to hire local worker in certain number or in formulation of percentage and the supervision mechanism toward the implementation and the sanction of it also being regulated within this local government regulation.

In any regulation contain permits or licensing should be worked together with those that regulate about manpower. Thus there is a synchronization regulation between licensing and manpower. In order to make the absorption of local manpower effective then every local government need to make the local government regulation that regulates obligation of every tourism business to run their business within the region should hire local worker.

\section{ACKNOWLEDGEMENT}

The author would like to thank all the parties who have helped and contributed in the writing of this article, both those who contribute in the form of funding and critical ideas. Hopefully this paper can be useful theoretically and practically for the addition and development of knowledge, especially in the field of legal science.

\section{REFERENCES}

[1] Y. A. Rahayu, 3 Tahun Jokowi-JK, sektor pariwisata sumbang PDB tertinggi di ASEAN, Merdeka.com, October 17, 2017.

[2] S. Basah, Eksistensi dan Tolok Ukur Badan Peradilan Administrasi di Indonesia, Yogyakarta: Pustaka Pelajar. 1998.

[3] Ridwan, H. R, Hukum Administrasi Negara Cetakan Kedua, Yogyakarta: UII Press. 2003.

[4] Indonesian Law Number 23 Year 2014 About Regional Government

[5] Minister of Tourism Regulation Number 18 Year 2016 About Registration of Tourism Business 